\title{
Finding immune gene expression differences induced by marine bacterial pathogens in the Deep-sea hydrothermal vent mussel Bathymodiolus azoricus
}

\author{
E. Martins ${ }^{1,2}$, A. Queiroz ${ }^{3}$, R. Serrão Santos $^{1,2}$, and R. Bettencourt ${ }^{2}$ \\ ${ }^{1}$ Department of Oceanography and Fisheries, University of the Azores (DOP/UAç), Rua Prof. Doutor Frederico Machado, \\ 9901-862 Horta, Portugal \\ ${ }^{2}$ IMAR-Instituto do Mar/ Institute of Marine Research, Laboratory of Robotics and Systems in Engineering and Science \\ (LARSyS), 9901-862 Horta (Azores) Portugal \\ ${ }^{3}$ Instituto Politécnico de Viana do Castelo (IPVC), Escola Superior Agrária de Ponte de Lima (ESAPL), Refóios do Lima, \\ 4990-706 Ponte de Lima, Portugal \\ Correspondence to: R. Bettencourt (raul@uac.pt)
}

Received: 30 November 2012 - Published in Biogeosciences Discuss.: 14 February 2013

Revised: 4 July 2013 - Accepted: 26 September 2013 - Published: 14 November 2013

\begin{abstract}
The deep-sea hydrothermal vent mussel Bathymodiolus azoricus lives in a natural environment characterised by extreme conditions of hydrostatic pressure, temperature, $\mathrm{pH}$, high concentrations of heavy metals, methane and hydrogen sulphide. The deep-sea vent biological systems represent thus the opportunity to study and provide new insights into the basic physiological principles that govern the defense mechanisms in vent animals and to understand how they cope with microbial infections. Hence, the importance of understanding this animal's innate defense mechanisms, by examining its differential immune gene expressions toward different pathogenic agents. In the present study, B. azoricus mussels were infected with single suspensions of marine bacterial pathogens, consisting of Vibrio splendidus, Vibrio alginolyticus, or Vibrio anguillarum, and a pool of these Vibrio bacteria. Flavobacterium suspensions were also used as a non-pathogenic bacterium. Gene expression analyses were carried out using gill samples from infected animals by means of quantitative-Polymerase Chain Reaction aimed at targeting several immune genes. We also performed SDS-PAGE protein analyses from the same gill tissues.

We concluded that there are different levels of immune gene expression between the $12 \mathrm{~h}$ to $24 \mathrm{~h}$ exposure times to various bacterial suspensions. Our results from qPCR demonstrated a general pattern of gene expression, decreas-
\end{abstract}

ing from $12 \mathrm{~h}$ over $24 \mathrm{~h}$ post-infection. Among the bacteria tested, Flavobacterium is the bacterium inducing the highest gene expression level in $12 \mathrm{~h}$ post-infections animals. The $24 \mathrm{~h}$ infected animals revealed, however, greater gene expression levels, using $V$. splendidus as the infectious agent. The SDS-PAGE analysis also pointed at protein profile differences between $12 \mathrm{~h}$ and $24 \mathrm{~h}$, particularly evident for proteins of 18-20 KDa molecular mass, where most dissimilarity was found. Multivariate analyses demonstrated that immune genes, as well as experimental infections, clustered in discrete groups in accordance with the gene expression patterns induced by bacterial pathogens.

\section{Introduction}

Deep-sea hydrothermal vents were discovered in the seafloor where the oceanic crust is subjected to active volcanic occurrences such as the Mid-Atlantic Ridge (Childress et al., 1992). Chemosynthetic-based ecosystems are built around the deep-sea hydrothermal vents and support large microbial communities (Teske, 2009) and symbioses between dominant fauna and intracellular bacteria permitting the existence of animals and microbes under such extreme environments (Duperron et al., 2009). 
Deep-sea vent mussels of the Bathymodiolus genus are dominant members at hydrothermal vents and cold seep habitats. These mussels have the peculiarity of sheltering both endosymbiotic sulphide-oxidizing and methane-oxidizing bacteria in their gills (Salerno et al., 2005; De Chaine et al., 2006), thus supporting their endurance within this type of environment (Bettencourt et al., 2008). Bathymodiolus azoricus is the dominant species in deep-sea hydrothermal vents in the Azores region and is adapted to extreme conditions that are characterised by toxic concentrations of heavy metals, acidic pH and absence of light (Bettencourt et al., 2007; Colaço et al., 2010).

The innate immune system is the foremost line of host defense against microbial pathogens (Janeway and Medzhitov, 2002; Kumar et al., 2009). This system recognises conserved molecules of microbial origin found in bacteria, viruses, protozoa and fungi, and known as Microbial-Associated Molecular Patterns (MAMPs) (Akira and Hemmi, 2003; Medzhitov, 2007; Boudsocq et al., 2010), which elicits an initial response through host-activated Pattern Recognition Receptors (PRR) (Medzitov, 2001; Kumar et al., 2009). Consequently, the innate immune system acts to protect the individual from invasive agents by detecting molecular signatures of infection that in turn initiates effector responses (Bettencourt et al., 2010). Invertebrates and molluscan immune responses are notorious for their ability to defend themselves against bacteria, fungi, and parasites. Their first lines of defense against infectious agents are physical and chemical barriers, such as the shell and exoskeleton, and deterrent chemical compounds. Once these barriers are breached, humoral and cellular reactions are set to function through hemolymph constituents and hemocytes respectively (Galloway and Depledge, 2001). Likewise, in bivalves, cellular and humoral components are required for defense responses allowing them to overcome pathogens that are naturally present in marine environments (Labreuche et al., 2006). The main cellular immune response against pathogens in molluscan is phagocytosis (Cheng, 1981; Feng, 1988; May et al., 2001).

Vibrio bacteria are a major cause of disease occurring in the marine environment (Demírcan and Candan, 2006) causing high mortality in some bivalves (Beaz-Hidalgo et al., 2010). Although the pathologies caused by Vibrio in bivalves have been described since the 1960s (Paillard et al., 2004) to this day, some of these species, such as $V$. alginolyticus, $V$. splendidus, $V$. anguillarum, are still being reported in case studies. V. alginolyticus and V. splendidus cause histological lesions that affect mainly the mantle, the velum, and the connective tissue of infected organisms (Gómez-León et al., 2005). Even though Vibrio anguillarum is the most studied aetiological agent of vibriosis, other members of the genus Vibrio have been implicated in epizootics of cultured and wild marine fish and shellfish (Toranzo and Barja, 1990). The presence of Vibrio diabolicus has also been found at deepsea hydrothermal vents and more recently the presence of a phenotypically related pathogenic Vibrio species was also re- ported at deep-sea vent sites (Raguénès et al., 1997; Hasan et al., 2010). Moreover, a wide phylogenetic spectrum of marine Flavobacteria was found in deep-sea sediments mainly oxidizing thiosulfate bacteria and several species that cause diseases in freshwater fish (Bernardet et al., 1996; Teske et al., 2000; Alain et al., 2004).

In view of this, the problem of microbial threat and the need for immunity exist in deep sea mussels, however, differences in immune gene expression in animals living in such distinct habitats, are likely to occur as well as the expression of their immune discriminatory capabilities. In this context, experimental infections carried out with Vibrio alginolyticus, Vibrio splendidus, Vibrio anguillarum strains and Flavobacterium, were performed and subsequently the expression of vent mussel immune genes analysed by qPCR. Additionally, protein profiles were also analysed by SDS-PAGE. Our results suggest that there are significant differences in gene expression profiles between the immune genes studied, among several bacteria used, and over the course of time during infection.

\section{Material and methods}

\subsection{Biological samples collection}

The mussels were collected from the hydrothermal vent field Menez Gwen (850 m depth, 37 $50,8-37^{\circ} 51.6 \mathrm{~N}, 31^{\circ} 30$ $31^{\circ} 31.8 \mathrm{~W}$ ), with the French R/V "Pourquoi Pas?" using the Remote Operated Vehicle (ROV Victor 6000) (MoMARSAT cruise, 28 June-22 July 2011).

\subsection{Bacterial preparations and infections}

B. azoricus mussels collected at the Menez Gwen field, were maintained in $20 \mathrm{~L}$ seawater containing plastic vessels, artificially supplemented with methane $\left(\mathrm{CH}_{4}\right)$ and dissolved Sodium Sulfide $\left(\mathrm{Na}_{2} \mathrm{~S}\right)$ (Bettencourt et al., 2010; Colaço et al., 2010). Subsequently, six groups of 8 animals each, corresponding to six distinct experimental conditions, were set into $2 \mathrm{~L}$ seawater containing beakers. Mussels were then, infected with a suspension of marine bacterial pathogens, consisting of one of the following strains $V$. splendidus, $V$. alginolyticus, or $V$. anguillarum, and with a pool of the 3 Vibrio strains. As yet another distinct bacterium, a suspension of Flavobacterium was also used. The control condition was regarded as incubations with only in seawater. Vibrios were obtained from Dr. Bassem Allam (Stony Brook University, NY, USA) and from Dr. Antonio Figueras (CSIC, IIM, Vigo, Spain). Flavobacterium was isolated from a marine bacterial screening from Azorean seawater samples. The marine Flavobacterium used in this study was identified to its genus by 16S PCR amplicon sequencing (Bettencourt unpublished data). $25 \mathrm{~mL}$ of bacterial inoculums were prepared from overnight cultures grown at room temperature in Marine Broth (Difco ${ }^{\mathrm{TM}}$ Marine Broth 2216) $\left(\mathrm{OD}_{600}=1.5\right)$ and 
Table 1. Forward and reverse primer sequences of the target Immune response genes according to the immune functional categories, Recognition, Signaling, Transcription and Effector genes (Bettencourt et al., 2010), used in qPCR analyses.

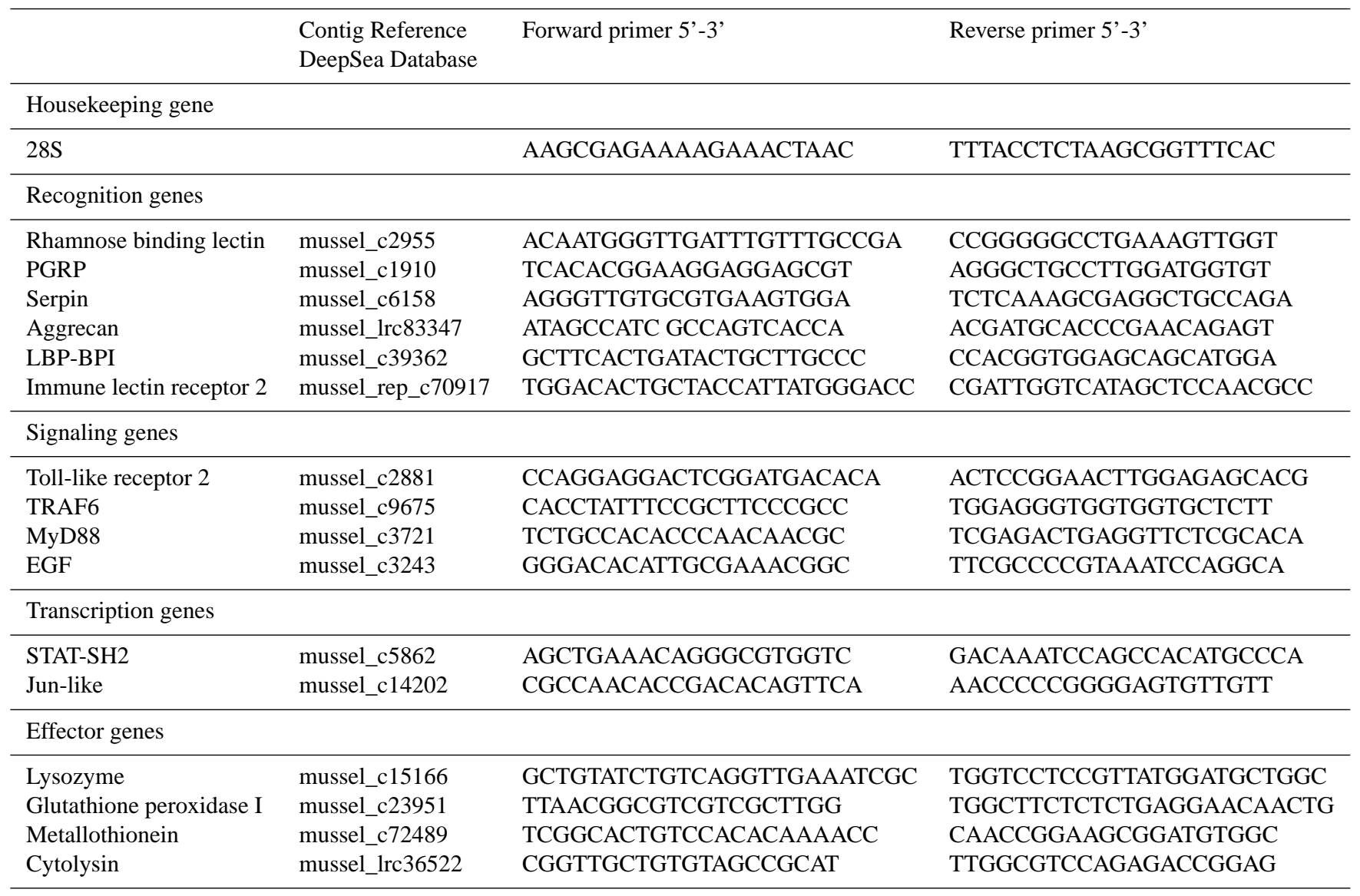

added as suspensions, to $2 \mathrm{~L}$ mussel containing beakers. Experimental infections were kept at $7-8^{\circ} \mathrm{C}$ in the LabHorta aquarium systems. Four animals from each experimental infection beaker were dissected at $12 \mathrm{~h}$ post-infection time and remaining four mussels dissected afterwards at $24 \mathrm{~h}$ postinfection time.

\subsection{Total RNA extraction}

Total RNA was extracted from gill tissues with TriReagent ${ }^{\circledR}$ (Ambion) and further purified with the RiboPure ${ }^{\mathrm{TM}} \mathrm{Kit}$ (Ambion) following the manufacturer's specifications and re-suspended in nuclease-free, DEPC-treated water. Total RNA quality preparations and concentrations were assessed by the $A_{260 / 280}$ and $A_{260 / 230}$ spectrophotometric ratios using the NanoVue spectrophotometer (General Electric, Healthcare Life Sciences. The cDNA was synthesized with SuperScript ${ }^{\mathrm{TM}}$ II Reverse Transcriptase (Invitrogen) according to the manufacturer's instructions, using $5 \mu \mathrm{g}$ total RNA per sample. Equal amounts of total RNA were used in all cDNA syntheses. The cDNA concentration was measured using the NanoVue spectrophotometer as above.

\subsection{Gene expression analyses}

Gene expression analyses from $12 \mathrm{~h}$ and $24 \mathrm{~h}$ post-infection gill samples were carried out using a mixture of four gill samples by means of quantitative PCR (qPCR) following the MIQE guidelines (Bustin et al., 2009). The immune genes selected in this study (Table 1), were Rhamnose-binding lectin, Peptidoglycan recognition protein (PGRP), Serpin, Aggrecan, Bactericidal/permeability-increasing proteinLipopolysaccharide-binding protein (BPI-LBP), Immune lectin receptor 2, Toll-like receptor 2, Tumor necrosis factor (TNF) receptor associated factor 6 (TRAF6), Myeloid differentiation primary response gene 88 (MyD88), Epidermal growth factor (EGF), STAT-SH2, Jun-like, Lysozyme, Glutathione peroxidase I, Metallothionein and Cytolysin gene. qPCR assays were performed with the CFX96 ${ }^{\mathrm{TM}}$ RealTime (Bio-Rad) using the same amount of cDNA concentration together with $10 \mu \mathrm{L}$ of SYBR ${ }^{\circledR}$ green (Fermentas), $1 \mu \mathrm{L}$ $(10 \mu \mathrm{M})$ forward primer, $1 \mu \mathrm{L}(10 \mu \mathrm{M})$ reverse primer and nuclease-free water in a final volume of $20 \mu \mathrm{L}$ per reaction.

The standard cycle conditions used in this study were $95^{\circ} \mathrm{C}$ for $10 \mathrm{~min}, 94^{\circ} \mathrm{C}$ for $20 \mathrm{~s}, 52^{\circ} \mathrm{C}$ for $20 \mathrm{~s}$ and $68^{\circ} \mathrm{C}$ for 
Table 2. Efficiency values for target genes according to the immune functional categories, Recognition, Signaling, Transcription and Effector genes.

\begin{tabular}{lr}
\hline Target genes & Efficiency values \\
\hline Housekeeping gene & \\
\hline $28 S$ & -3.16 \\
\hline Recognition genes & -3.25 \\
\hline Rhamnose binding lectin & -3.4 \\
PGRP & -3.91 \\
Serpin & -3.78 \\
Aggrecan & -3.2 \\
LBP-BPI & -3.11 \\
Immune lectin receptor 2 & -3.44 \\
\hline Signaling genes & -3.43 \\
\hline Toll-like receptor 2 & -3.6 \\
TRAF6 & -3.67 \\
MyD88 & \\
\hline EGF & -3.75 \\
\hline Transcription genes & -3.42 \\
\hline STAT-SH2 & -3.13 \\
\hline Jun-like & -3.33 \\
\hline Effector genes & -21 \\
\hline Lysozyme & \\
Glutathione peroxidase I & \\
Metallothionein & \\
Cytolysin & \\
\hline & \\
\hline
\end{tabular}

$30 \mathrm{~s}$ followed by 40 cycles of $65^{\circ} \mathrm{C}$ for $5 \mathrm{~min}$ and $95^{\circ} \mathrm{C}$ for $5 \mathrm{~min}$. Gene expressions quantifications were normalised using the 28S ribosomal RNA gene as the housekeeping gene. Data analyses were based on the $\Delta \Delta \mathrm{C}_{t}$ method with normalisation of the raw data to the housekeeping gene expression values. The forward and reverse sequences used in qPCR are shown in Table 1. Two technical replicates were obtained from qPCR and data were expressed as means and Standard Deviation.

The immune genes analysed in the present study, were categorised into four groups of functional genes referred as Recognition, Signaling, Transcription and Effector genes (Bettencourt et al., 2010). The primer pair efficiency (Table 2) was analysed in consecutive dilutions of cDNA through the regression line of the cycle thresholds $(\mathrm{Ct})$ versus the relative concentration of cDNA (Livak and Schmittgen, 2001).

\subsection{Statistical analyses}

The statistical analyses were performed with the software package IBM SPSS Statistic 19 and R software. The gene expression data were expressed as Mean \pm Standard Deviation
(SD). The differences in gene expression, bacterial exposure effect and the duration of experimental infections $(12 \mathrm{~h}$ and $24 \mathrm{~h}$ post-infection) were evaluated using analysis of variance; where the assumption of normality and homogeneity of variances (Leven's test) was not met, non-parametric tests such as Mann-Whitney's were used instead. Significance levels for tests were $5 \%$. These analyses together with the post-hoc Tukey HSD test were done with the SPSS Statistic 19 software. Multivariate analysis was conducted with $\mathrm{R}$ software, and cluster analysis performed on the euclidian distance matrix using the UPGMA (Unweighted Pairgroup Method using Arithmetic Average) method. Results from qPCR were subjected to Hierarchical clustering dendrograms using UPGMA method and taking into account, on the one hand, the experimental infections clustering (Flavobacterium, Pool, V. anguillarum, V. splendidus, V. alginolyticus and Control), established for $12 \mathrm{~h}$ (Fig. 2) and on the other hand, same experimental infections clustering for $24 \mathrm{~h}$ (Fig. 3) post-infection times. This method was also applied for gene cluster dendrograms set for $12 \mathrm{~h}$ (Fig. 4) and $24 \mathrm{~h}$ (Fig. 5) post-infection times. In addition, Heatmaps were produced and showed (Figs. 6 and 7). The Penalty function of KGS (Grum and Atieno, 2007) was used to find the appropriate number of clusters.

\subsection{SDS-PAGE}

Gills from B. azoricus animals infected with the marine bacterial pathogens, $V$. splendidus, $V$. alginolyticus, $V$. anguillarum, a pool of these Vibrios, and Flavobacterium were used for protein assessment and separation in polyacrylamide gel electrophoresis experiments. Control gill samples from animals bathing in seawater were also analysed. SDS-PAGE analyses were carried out with homogenates consisting of four gills mixtures corresponding to $12 \mathrm{~h}$ and $24 \mathrm{~h}$ post infection times. Gill samples were prepared with $2 \mathrm{~mL}$ of a $45 \mathrm{~mL}$ solution consisting of $500 \mu \mathrm{L} 0.1 \mathrm{MDTT}, 500 \mu \mathrm{L}$ Protease Arrest ${ }^{\mathrm{TM}} 100 \mathrm{x}$ (Calbiochem $\left.{ }^{\circledR}\right), 500 \mu \mathrm{L}$ EDTA $0.5 \mathrm{M}$ $100 \times, 200 \mu \mathrm{L}$ Triton ${ }^{\circledR} \mathrm{X}-100,500 \mu \mathrm{L}$ SDS $10 \%$ and TrisHCL $6.8 \mathrm{pH}$. Homogenates were centrifuged at $4000 \mathrm{rpm}$ for $15 \mathrm{~min}$, at $4{ }^{\circ} \mathrm{C}$, followed by a second centrifugation at $13200 \mathrm{rpm}$ for $30 \mathrm{~min}$, at $4^{\circ} \mathrm{C}$. Afterwards, to the supernatants equal volume of $1 \mathrm{X}$ (Applichem A3484) loading buffer was added.

The samples were denatured at $95^{\circ} \mathrm{C}$, for $10 \mathrm{~min}$, in a water bath and subsequently, centrifuged at $13200 \mathrm{rpm}$ for $30 \mathrm{~min}$. The supernatant was then loaded onto pre-cast 4 $12 \%$ Bis-Tris NuPAGE ${ }^{\circledR}$ Novex polyacrylamide gels (Invitrogen) and ran with $1 \mathrm{X}$ NuPAGE$^{\circledR}$ MES running buffer at $90 \mathrm{~V}$ for $1 \mathrm{~h}$.

A reference protein (around $28 \mathrm{KDa}$ ) was visually examined, in all samples, to be used as a protein loading control reference in $12 \mathrm{~h}$ and $24 \mathrm{~h}$ post-infection protein samples. $5 \mu \mathrm{L}$ protein ladder (SeeBlue ${ }^{\circledR}$ Pre-Stained Standard Invitrogen) were loaded separately for protein molecular mass 
determination. Coomassie blue solution (Phast Gel TM Blue Tablet R, GE Healthcare) was used for Gel staining, during $1 \mathrm{~h}$, at $45^{\circ} \mathrm{C}$ with gentle agitation, following the manufacturer's instructions. Gels were rinsed twice with destain solution $(70 \%$ distilled water, $20 \%$ methanol and $10 \%$ acetic acid glacial), under gentle agitation, for $1 \mathrm{~h}$, at $45^{\circ} \mathrm{C}$ until protein bands were adequately visualised.

\section{Results}

In vivo incubation experiments carried out with different live Vibrio strains and Flavobacterium induced differential gene expression at $12 \mathrm{~h}$ and $24 \mathrm{~h}$ post-infection times. Among the functional category "recognition genes" tested, the Immune lectin receptor 2 revealed the highest expression level, at $12 \mathrm{~h}$ infection, in the presence of Flavobacterium whereas incubations with V. alginolyticus and the pool of Vibrios resulted in a slightly above seawater-incubation control expression level for this immune gene (Fig. 1a). Similarly, the Serpin gene was induced to its highest level by Flavobacterium and to a lesser extent by V. anguillarum (Fig. 1a). Gene expression results obtained for the Rhamnose-binding lectin, PGRP, Aggrecan, LPB-BPI were below seawater-incubation gene expression levels suggesting that $B$. azoricus gill tissues retain an immune discriminatory capacity while inducing differential transcript expressions, relative to the microorganism tested in comparison to seawater expression levels. In some cases, up-regulation was seen for the Immune lectin receptor 2 in the presence of Flavobacterium whereas downregulation was observed for the same gene in the presence of $V$. splendidus and $V$. anguillarum (Fig. 1a). The $24 \mathrm{~h}$ postinfection transcriptional activity was significantly different from the transcriptional activity at $12 \mathrm{~h}$ post-infection time (Mann-Whitney test Sig $=0$ ). At $24 \mathrm{~h}$, the Immune lectin receptor 2 gene presented again the highest level of expression among the immune recognition genes tested, in the presence of V. splendidus, in contrast to what was observed for Flavobacterium at $12 \mathrm{~h}$. The Immune lectin receptor 2 upregulation is still noticeable for $V$. anguillarum and the pool of Vibrios, in divergence to the effect seen with $V$. alginolyticus whether at $12 \mathrm{~h}$ or $24 \mathrm{~h}$ post-infection (Fig. 1b).

Regarding the functional category "signaling genes", $B$. azoricus infected with $V$. alginolyticus revealed the highest expression level for Toll-like receptor 2 (TLR2) at $12 \mathrm{~h}$ time point, followed by Flavobacterium and to a lesser extent by V. splendidus (Fig. 1c). In the same way, MyD88 gene was induced to its highest level by Flavobacterium and also by $V$. alginolyticus compared to the control seawater-incubation animals. On the contrary, down-regulation was observed for the same gene in the presence of $V$. splendidus, the pool of Vibrios and V. anguillarum (Fig. 1c). The $24 \mathrm{~h}$ post-infection transcriptional activity was different to that of the $12 \mathrm{~h}$ infection time. The TLR2 gene presented again the highest level of expression among the signaling genes tested, in the presence of $V$. splendidus at $24 \mathrm{~h}$ in contrast to gene expressions values obtained with $V$. alginolyticus at $12 \mathrm{~h}$. Below-seawater control gene expression levels were found for TRAF6, MyD88 and EGF. Moreover, TLR2 was up-regulated in the presence of V. splendidus and the pool of Vibrios at $24 \mathrm{~h}$ (Fig. 1d).

As for the category "transcription genes", Jun-like gene revealed the highest expression level at $12 \mathrm{~h}$ infection, in the presence of Flavobacterium as well as for the pool of Vibrios (Fig. 1e). On the other hand, infections carried out with $V$. splendidus, V. alginolyticus and V. anguillarum showed reduced expression for STAT-SH2 gene and Jun-like gene at $12 \mathrm{~h}$ infection (Fig. 1e). The $24 \mathrm{~h}$ post-infection transcriptional activity revealed some differences, as for the STATSH2 gene and Jun-like which presented an increase level of expression in the presence of $V$. splendidus at $24 \mathrm{~h}$, as opposed to what was observed at $12 \mathrm{~h}$. At $24 \mathrm{~h}$, Jun-like gene revealed the highest expression level in $V$. splendidus infections. Below seawater-incubation gene expression levels were found in the presence of $V$. alginolyticus, $V$. anguillarum, pool of Vibrios and Flavobacterium at $24 \mathrm{~h}$ (Fig. 1f).

Within the immune category "effector genes", Lysozyme showed the highest expression level, in $12 \mathrm{~h}$ Flavobacterium infections (Fig. 1g). However, Metallothionein and Glutathione peroxidase I revealed some expression compared to the control seawater-incubation group of animals, in the presence of the same bacterium, at $12 \mathrm{~h}$ (Fig. $1 \mathrm{~g}$ ). Moreover, the effector genes showed down-regulation in the presence of $V$. splendidus, $V$. alginolyticus, $V$. anguillarum and the pool of Vibrios (Fig. 1g). The $24 \mathrm{~h}$ post-infection transcriptional activity for cytolisin revealed a higher expression level compared to $12 \mathrm{~h}$ (Fig. 1h).

The statistical analyses applied to our experimental conditions, evidenced significant differences $(p<0,05)$ within the expression levels at $12 \mathrm{~h}$ and $24 \mathrm{~h}$ post infection, and also between levels of gene expression. These analyses include Mann-Whitney test $(\mathrm{Sig}=0)$ and ANOVA with posthoc Tukey HSD test. At $12 \mathrm{~h}$ infection time, $69 \%$ of the genes were up-regulated whereas $31 \%$ were down-regulated. At $24 \mathrm{~h}$ infection time, $37.5 \%$ of the genes were up-regulated whereas $62.5 \%$ were down-regulated genes. When comparing the number of genes induced by bacteria, at $12 \mathrm{~h}, V$. splendidus induced $5 \%$ of the total genes, $V$. alginolyticus induces $17 \%$, V. anguillarum 5\%, the pool of Vibrios $17 \%$ and Flavobacterium $56 \%$ of the total genes. At $24 \mathrm{~h}, \mathrm{~V}$. splendidus induced $50 \%$ of the total genes, $V$. alginolyticus induced $0 \%$, V. anguillarum $10 \%$, the pool of Vibrios $30 \%$ and Flavobacterium $10 \%$ of the total genes (Fig. 8).

Our descriptive data analyses were followed by multivariate statistical analyses to better illustrate how vent mussels respond to bacterial infections while up-regulating and down-regulating immune genes during bacterial infections and allow for exploratory analysis to see how the gene expression results group together based on similarity of features, and thus testing the premise that their innate immune system is capable of discriminating different Vibrio strains. 

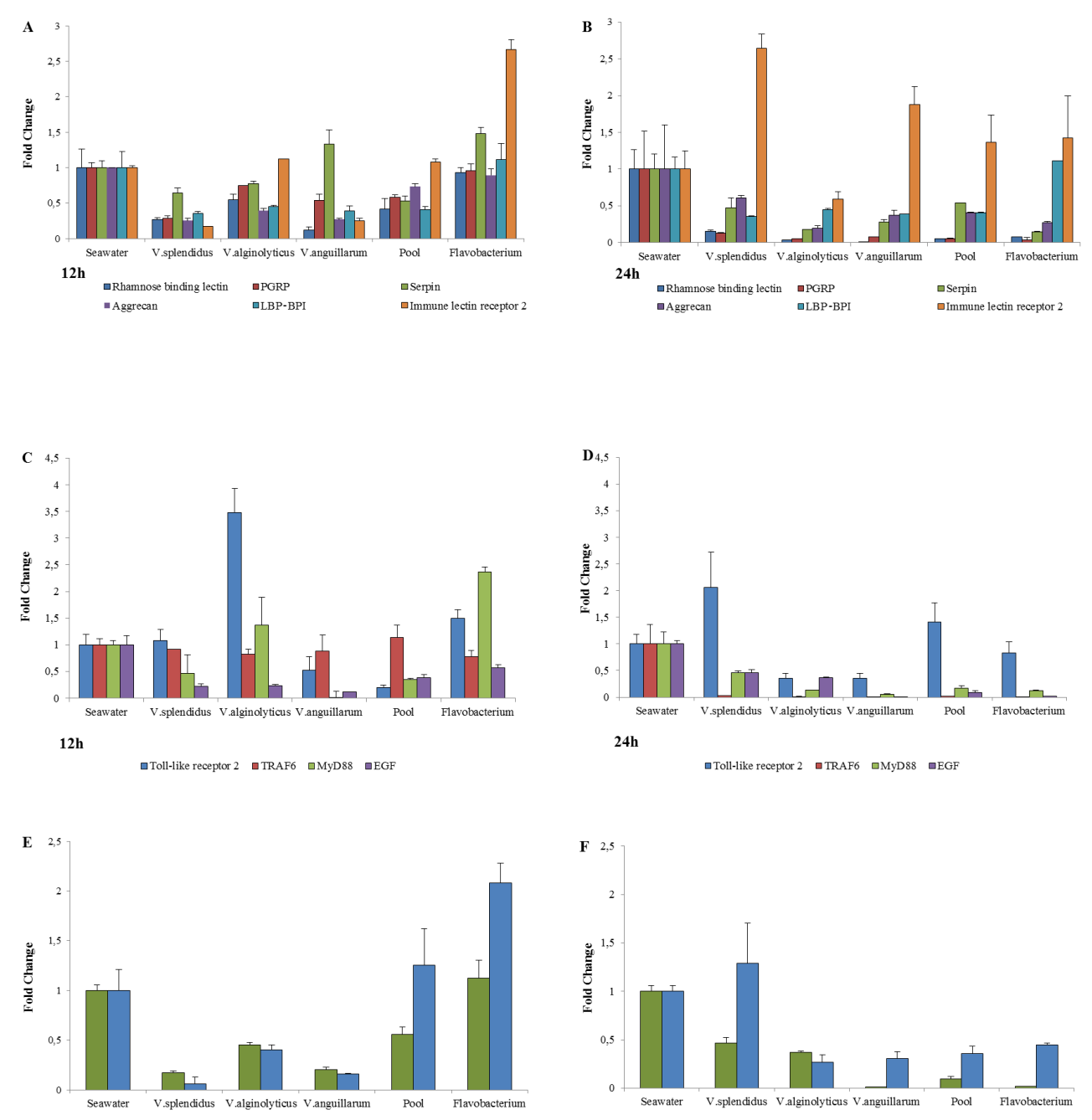
$12 \mathrm{~h}$

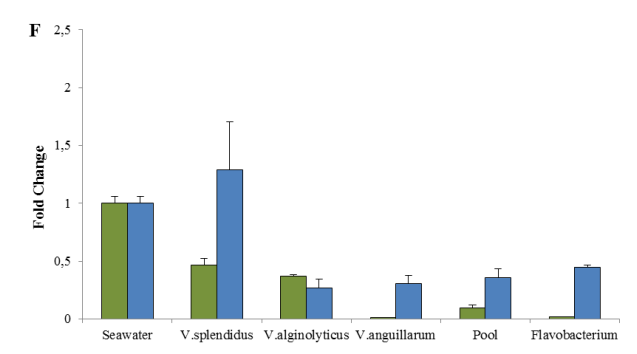

$24 h$
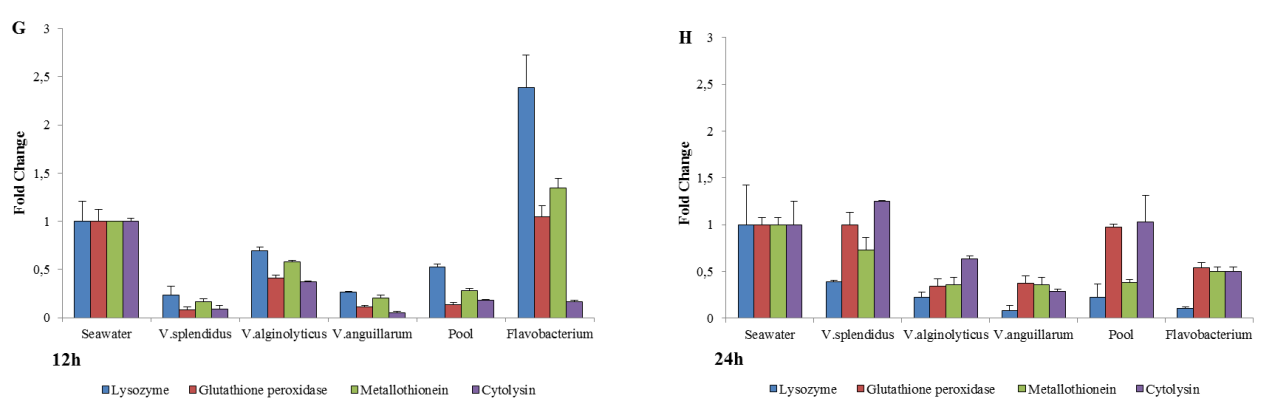

Fig. 1. Differential expression of immune genes. (A) Expression levels of immune recognition genes (Rhamnose-binding lectin, PGRP, Serpin, Aggrecan, LBP-BPI and Immune lectin receptor 2) from B. azoricus infected gills at $12 \mathrm{~h}$ infection time. (B) Expression levels of immune recognition genes as in (A), from B. azoricus infected gills at $24 \mathrm{~h}$ infection time. (C) Expression levels of immune signaling genes (Toll-like receptor 2, TRAF6, MyD88 and EGF) from B. azoricus infected gills at $12 \mathrm{~h}$ infection time. (D) Expression levels of immune signaling genes as in $(\mathbf{C})$, at $24 \mathrm{~h}$ infection time. (E) Expression levels of immune transcription genes (STAT-SH2 and Jun-like) from B. azoricus infected gills at $12 \mathrm{~h}$ infection time. (F) Expression levels of immune transcription genes as in (E), at $24 \mathrm{~h}$ infection time. (G) Expression levels of immune effector genes (Lysozyme, Glutathione peroxidase, Metallothionein and Cytolysin) from B. azoricus infected gills at $12 \mathrm{~h}$ infection time. (H) Expression levels of immune effector genes as in (G), at $24 \mathrm{~h}$ infection time. Data expressed as Means and Standard Deviation with two technique replicates. Bars represent the level expression (Fold change) of target gene, in different experimental conditions, and normalised to the housekeeping gene $28 \mathrm{~S}$. 
Cluster Dendrogram

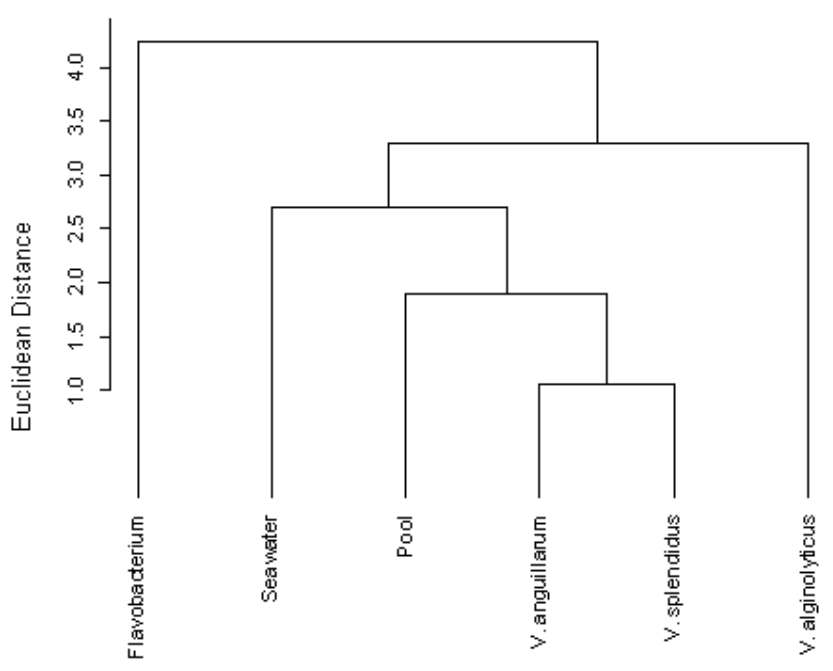

Fig. 2. Hierarchical clustering Dendrogram of Experimental condition (Flavobacterium, pool of Vibrios, V. anguillarum, V. splendidus, V. alginolyticus) and Control (Seawater) of mussel B. azoricus at $12 \mathrm{~h}$ post-infection through Euclidean distance, using UPGMA method.

The hierarchical clustering dendrogram demonstrated how data originated from bacterial infections and from controlseawater conditions were clustered together with the quantitative gene expression pattern they determined. Four cluster dendrograms were considered with the analysis of bacterial infection conditions results obtained at $12 \mathrm{~h}$ incubation time (Fig. 2). The first cluster was formed with Flavobacterium which caused distinct responses in B. azoricus. The second cluster included seawater-incubation samples, regarded as our experimental control. The third cluster was formed with the pool of Vibrios, $V$. anguillarum and $V$. splendidus and the fourth cluster was formed with V. alginolyticus infection. This is in agreement with the levels of gene expressions for Immune lectin receptor 2 and Toll-like receptor 2 (Fig. 1a and $b$ ).

As for the cluster dendrogram results obtained for $24 \mathrm{~h}$ incubation time (Fig. 3), three clusters were defined, which in this case included a cluster consisting of the control seawaterincubation samples, a second consisting of V. splendidus, and a third cluster formed upon the remaining Vibrio, the pool of Vibrios and Flavobacterium results This correlates with $V$. splendidus infection, that results, in this study, in upregulated immune genes (Fig. 1b, d, f and h).

The multivariate statistical analyses also provided a representation on how signaling pathways may be selectively activated in $B$. azoricus during immune responses triggered by marine bacteria over the course of infection. Clustering gene expression data using hierarchical clustering $\mathrm{R}$ analysis, relative to $12 \mathrm{~h}$ (Fig. 4) and $24 \mathrm{~h}$ post-infection (Fig. 5), gave rise to a gene cluster dendrogram where fours clusters were

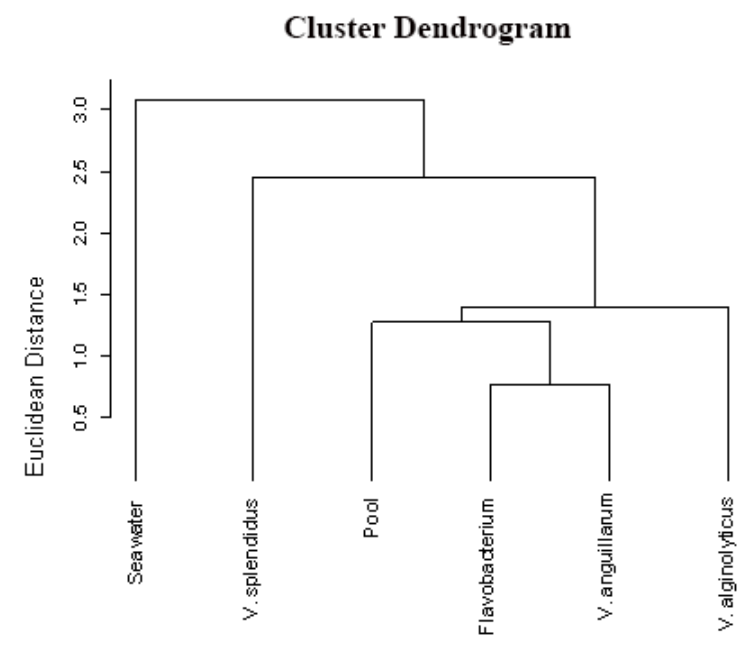

Fig. 3. Hierarchical clustering Dendrogram of Experimental condition (Flavobacterium, pool of Vibrios, V. anguillarum, V. splendidus, V. alginolyticus) and Control (Seawater) of mussel B. azoricus at $24 \mathrm{~h}$ post-infection through Euclidean distance, using UPGMA method.

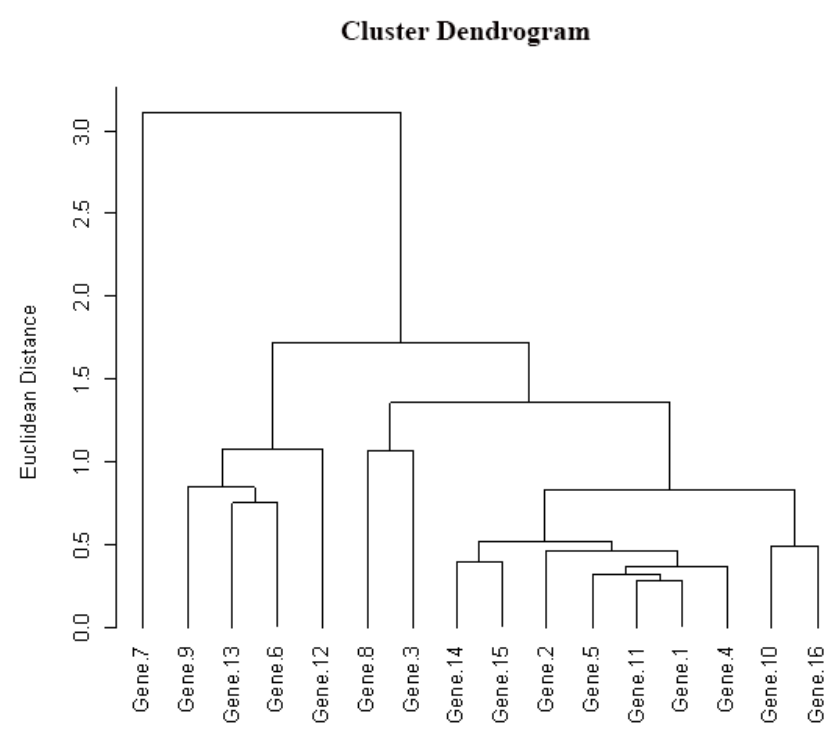

Fig. 4. Gene Cluster Dendrogram of mussel B. azoricus at $12 \mathrm{~h}$ post-infection through Euclidean distance, using UPGMA method. The numeration of Genes represent: (1) Rhamnose binding lectin; (2) PGRP; (3) Serpin; (4) Aggrecan; (5) LBP-BPI; (6) Immune lectin receptor 2; (7) Toll-like receptor 2; (8) TRAF6; (9) MyD88; (10) EGF; (11) STAT-SH2; (12) Jun-like; (13) Lysozyme; (14) Glutathione peroxidase I; (15) Metallothionein and (16) Cytolysin.

evidenced. In Fig. 4 (12 h) a first cluster was constituted only by the Toll-like receptor 2 (TLR2) gene. The fact that TLR2 is included as in one single cluster is coincident with its distinctiveness in our gene expression studies. It represents the most inducible of the signaling genes for both $12 \mathrm{~h}$ and $24 \mathrm{~h}$ infections (Fig. 1c and d). A second cluster was formed with 


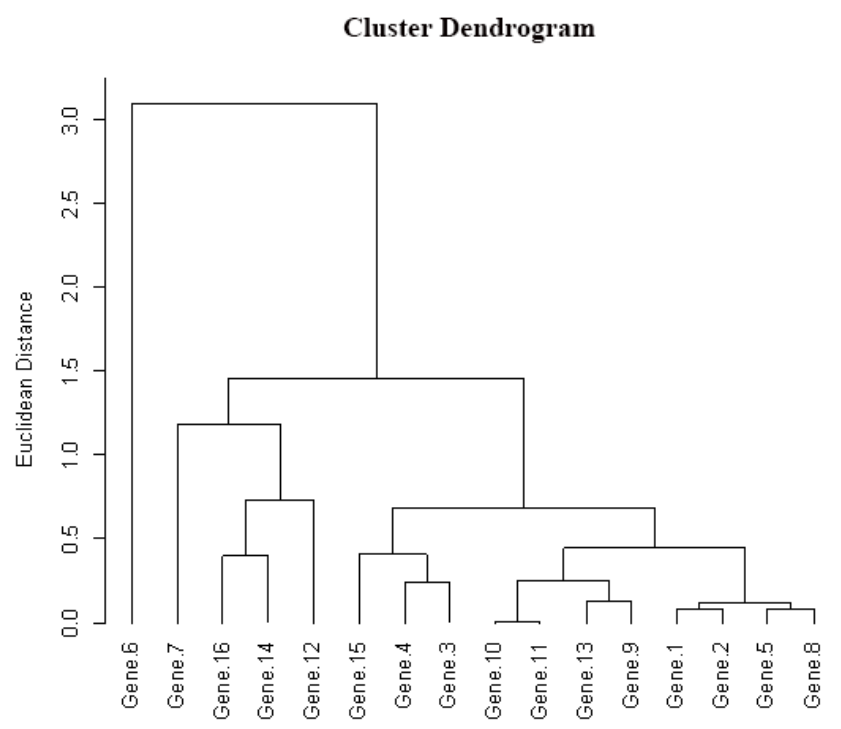

Fig. 5. Gene Cluster Dendrogram of mussel B. azoricus at $24 \mathrm{~h}$ post-infection through Euclidean distance, using UPGMA method. The numeration of Genes represent: (1) Rhamnose binding lectin; (2) PGRP; (3) Serpin; (4) Aggrecan; (5) LBP-BPI; (6) Immune lectin receptor 2; (7) Toll-like receptor 2; (8) TRAF6; (9) MyD88; (10) EGF; (11) STAT-SH2; (12) Jun-like; (13) Lysozyme; (14) Glutathione peroxidase I; (15) Metallothionein and (16) Cytolysin.

MyD88, Lysozyme, Immune lectin receptor 2 and Jun-like genes. A third cluster included TRAF6 and Serpin gene, both genes, putatively involved in the Toll signaling pathway. A fourth cluster was formed with Glutathione peroxidase, Metallothionein, PGRP, LBP-BPI, STAT-SH2, Rhamnose binding lectin, Aggrecan, EGF and Cytolysin genes (Fig. 4).

The genes cluster dendrogram regarding expression levels obtained at $24 \mathrm{~h}$ incubation time (Fig. 5), indicated that four clusters were obtained. The first cluster was formed with Immune lectin receptor 2 and second cluster by TLR2. The third cluster was formed with Cytolysin, Glutathione peroxidase and Jun-like. The remaining genes were grouped in a fourth cluster (Fig. 5).

Our statistical analyses also included Heatmaps to illustrate how differential gene expression data group together based on similarities of features between the experimental conditions, control seawater, $V$. splendidus, V. alginolyticus, $V$. anguillarum, the pool of Vibrios and Flavobacterium incubations data and the expression of sixteen immune genes at $12 \mathrm{~h}$ (Fig. 6) and $24 \mathrm{~h}$ post-infection times (Fig. 7).

As for the gene cluster dendrograms, the TLR2 gene was expressed to its highest level upon $V$. alginolyticus infection which is visualised in the Heatmap as a dark pink colour whereas for other Vibrio infections, lower levels of expression are represented by other colours. The lowest level of expression is represented by a dark blue colour such as in the case of pool of Vibrios infection. The Heatmap corresponding to $24 \mathrm{~h}$ post-infection results (Fig. 7), indicates the

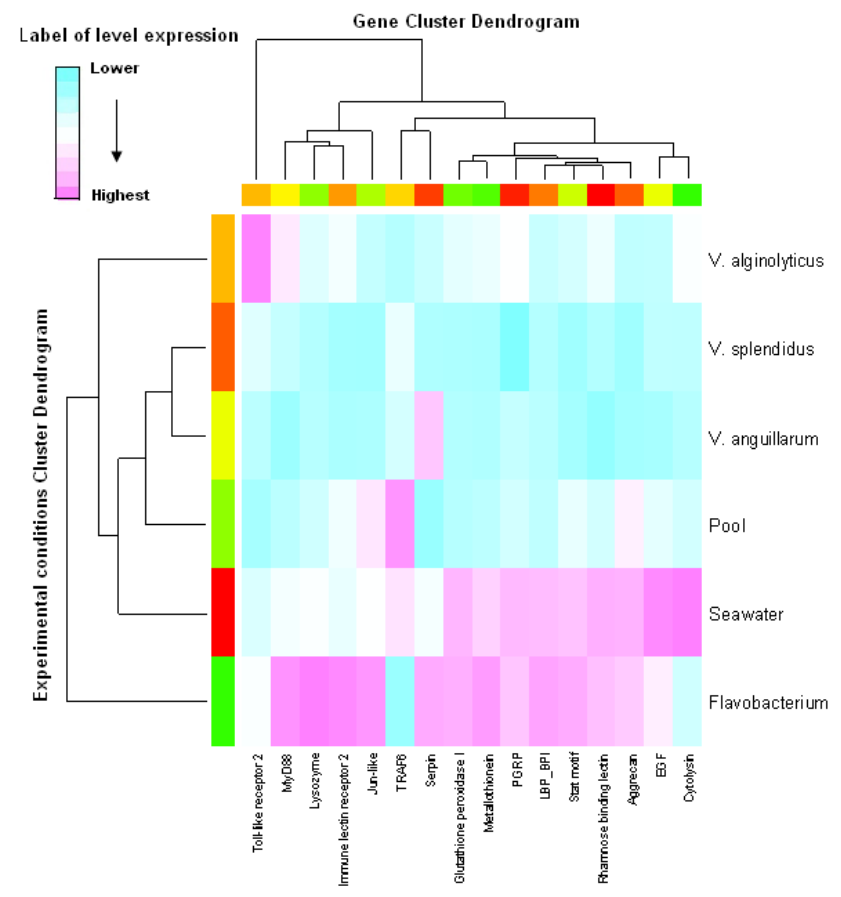

Fig. 6. Hierarchical Clustering Heatmap Plot of dendrograms using Unweighted Pair Group Method with Arithmetic Mean (UPGMA) method. The heatmap represents a grid of coloured points where each colour represents a level of gene expression (Fold change). The rows represent Experimental conditions ( $V$. alginolyticus, $V$. splendidus, V. anguillarum, pool of Vibrios, Seawater and Flavobacterium) and the columns represent 16 genes analysed at $12 \mathrm{~h}$ of infections. The grid coordinates correspond to the sample by gene combinations where the dark pink colour corresponds the highest expression and dark blue corresponds to the lowest expression.

down-regulation of the Metallothionein, Serpin, EGF, STATSH2, Lysozyme, MyD88, Rhamnose-binding protein, PGRP, LBP-BPI and TRAF6 genes, whereas Glutathione peroxidase I showed a similar level of expression as the control seawater, V. splendidus and the pool of Vibrios incubations.

The SDS-PAGE protein analyses revealed some differences between B. azoricus gill samples from the $12 \mathrm{~h}$ to $24 \mathrm{~h}$ infection experiments (Fig. 9). A reference protein band corresponding to $28 \mathrm{KDa}$ was used as a protein loading control in 1-D comparative protein electrophoresis using samples from $12 \mathrm{~h}$ and $24 \mathrm{~h}$ Vibrios and Flavobacterium infections. This reference protein band (Appendix A) was subsequently analysed by mass spectrometry followed by Mascot searches based on probability Mowse Score revealing homologies with a Branchiostoma floridae hypothetical protein (score 119 with $99 \%$ homology) and to actin proteins by searches in the NCBI database (Table 3, Appendix A). The rectangles highlight the reduced amount of bands from $12 \mathrm{~h}$ to $24 \mathrm{~h}$ and the white bracket suggests an increase of the bands at $12 \mathrm{~h}$ infection (Fig. 9). 


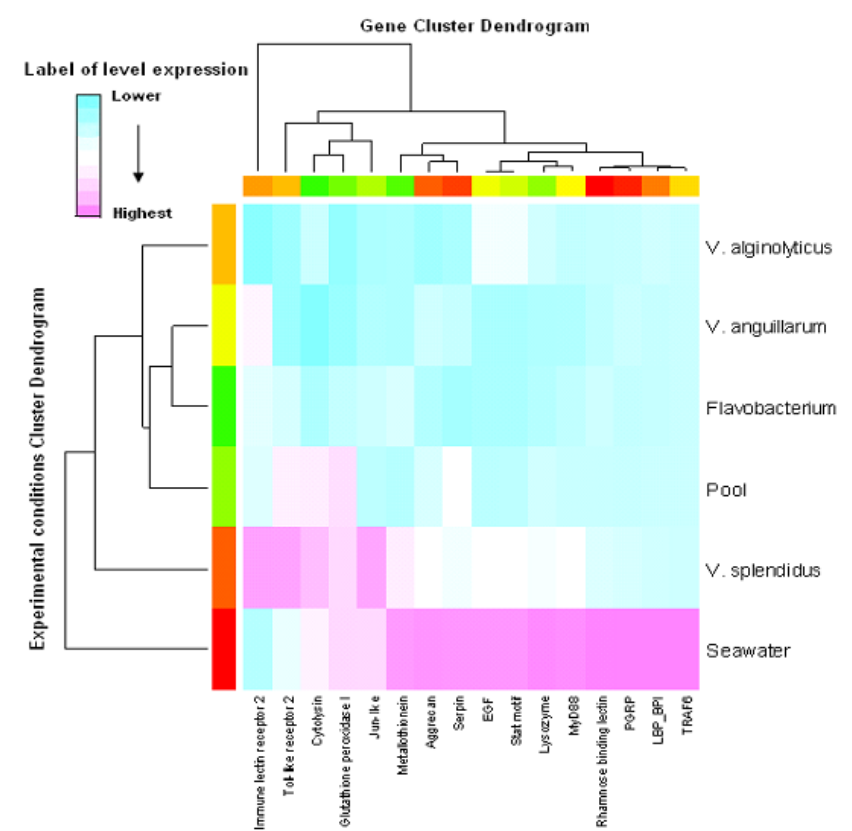

Fig. 7. Hierarchical Clustering Heatmap Plot of dendrograms using Unweighted Pair Group Method with Arithmetic Mean (UPGMA) method. The heatmap represents a grid of coloured points where each colour represents a level of gene expression (Fold change). The rows represent Experimental conditions ( $V$. alginolyticus, V. splendidus, V. anguillarum, pool of Vibrios, Seawater and Flavobacterium) and the columns represent 16 genes analysed at $24 \mathrm{~h}$ of infections. The grid coordinates correspond to the sample by gene combinations where the dark pink colour corresponds the highest expression and dark blue corresponds to the lowest expression.

SDS-PAGE comparison protein profiles using samples from $12 \mathrm{~h}$ and $24 \mathrm{~h}$ infection time, revealed differences around $18 \mathrm{kDa}$ regardless of the bacteria used. Within this electrophoretic mobility area, the occurrence of inducible bands was visible for $24 \mathrm{~h}$ samples whereas in the $12 \mathrm{~h}$ samples these were still not evidenced (Fig. 9).

\section{Discussion}

Understanding the molecular mechanisms underlying defense reactions and the activation of genes involved in signaling pathways leading to innate immune responses, may provide helpful information, on how animals respond to environmental microorganisms that in the case of vent mussels may involve interaction with potential pathogens from the surrounding vent environment. The present studies presented a first insight into how vent mussels may respond to the presence of distinct marine bacteria bringing evidence for immune discriminatory capabilities not seen in previous studies conducted with deep-sea vent organisms. We have addressed the problem of microbial threat and the need for immunity that must exist in the deep-sea mussels as for their congeners living in estuarine environments, them too, subjected to microbial threat while focusing our gene expression analyses on "canonical" immune genes already evidenced in our and others previous studies, more so, when new sequencing techniques were made available such as next generation sequencing methods, high-throughput deep sequencing, applied to de novo transcriptome sequencing (454 and illumina). Our transcriptome sequencing, published in 2010, provided a source of data for the discovery and identification of new genes of which several putative immune genes were revealed and their physical nature put in evidence by means of qPCR (Bettencourt et al., 2010).

Our results suggest that $B$. azoricus is equipped with discriminatory capabilities in that it enables distinct responses to marine bacterial pathogens such as V. splendidus, V. alginolyticus, $V$. anguillarum and Flavobacterium. The gene targets tested showed differences in expression over infection time and nature of the bacterium used and thus pointing at a dual modulation of gene expression and immune discriminatory capabilities of the host vent mussel. The TLR2 expression profiles are in agreement with a role in the recognition of different bacterial infectious strains while expressing distinctively according to the Vibrio strain and time of infection. TLR2 presented distinct expression levels at $12 \mathrm{~h}$ and $24 \mathrm{~h}$ of infection as demonstrated by its down-regulation upon $V$. anguillarum incubation and up-regulation upon V. alginolyticus within the same $12 \mathrm{~h}$ post-infection time (Fig. 1c). This suggested that pathogens activate different transcriptional activities of genes involved in signaling pathways such as the TLR2. The TLR family includes receptors found both at the intracellular level and cell surface triggering the induction of cytokines essential for the innate immune response following the recognition of microbial products and foreign nucleic acids, the signature of invading viruses and certain bacteria, sensed intracellularly (Blasius and Beutler, 2010). The fact that TLR2 is included as in one single hierarchical dendrogram cluster is coincident with its singularity during our gene expression studies. It represents the most inducible of the signaling genes for both $12 \mathrm{~h}$ and $24 \mathrm{~h}$ infections (Fig. 1c and d). MyD88 is another signaling molecule that is involved in the intracellular homeostasis, through phagocytosis and the synthesis of microbial effector molecules (Sancho and Sousa, 2012) such as lysozyme and thus represents a key protein in the innate immune responses of invertebrates against bacterial infections (Zhao et al., 2010). This is corroborated by gene expression results for Immune lectin receptor 2, MyD88 and lysozyme which were up-regulated in mussels infected with Flavobacterium at $12 \mathrm{~h}$ suggesting that B. azoricus was under high immune transcriptional activity due to infection since these genes are involved in opposing and eliminating pathogenic microorganisms.

Lectins constitute a group of sugar-binding proteins that recognise specific carbohydrate structures allowing agglutination of foreign cells and the stimulation of phagocytosis (Endo et al., 2010; Kilpatrick, 2002) assuming a crucial role 
Percentage of Expression Gene Levels at $12 \mathrm{~h}$ and $24 \mathrm{~h}$

A) $12 \mathrm{~h}$

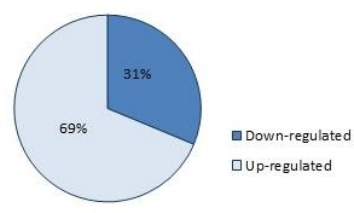

B) $24 \mathrm{~h}$

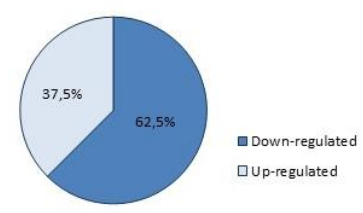

Percentage of Bacterial Infections at $12 \mathrm{~h}$ and $24 \mathrm{~h}$

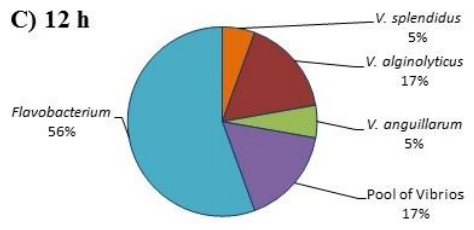

D) $24 \mathrm{~h}$

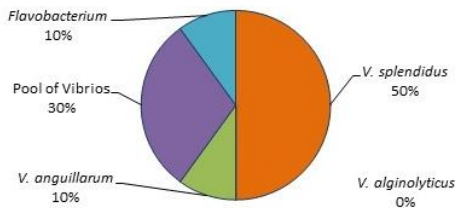

Fig. 8. Percentage of gene expression levels and percentage of genes induced by bacterial infections at $12 \mathrm{~h}$ and $24 \mathrm{~h}$ infection time based on qPCR results. (A) and (B) Percentage of down- and up-regulated genes at $12 \mathrm{~h}$ and $24 \mathrm{~h}$ respectively. (C) and (D) Percentage of genes induced by bacterial infections (V. splendidus, V. alginolyticus, V. anguillarum, pool of Vibrios and Flavobacterium) based on percentage of up-regulated genes in B. azoricus.

Table 3. Mascot search results of B. azoricus peptides that match with sequence of Accession Nr., Mass, Score and Description that was based on probability Mowse Score.

\begin{tabular}{llcl}
\hline Accession Nr. & Mass & Score & Description \\
\hline gi|260794036 & 41966 & 119 & hypothetical protein BRAFLDRAFT_114535 [Branchiostoma floridae] \\
gi|344250136 & 27440 & 111 & Actin, cytoplasmic 2 [Cricetulus griseus] \\
gi|169643685 & 39426 & 110 & beta actin isoform 1 [Solea senegalensis] \\
gi|4376057 & 420709 & 110 & actin [Oreochromis mossambicus] \\
gi|3182897 & 41971 & 109 & RecName: Full= Actin, cytoplasmic; Contains: RecName: Full = Actin, cytoplasmic, N-terminally processed \\
gi|229472802 & 41993 & 109 & actin [Crassostrea gigas] \\
gi|118419975 & 40937 & 108 & beta-actin [Megaptera novaeangliae] \\
gi|238866623 & 12076 & 106 & beta-actin [Menidia beryllina] \\
gi|298155653 & 922284 & 105 & actin [Nectria cyanostoma] \\
gi|84314104 & 22492 & 105 & actin [Trichoderma ovalisporum] \\
\hline
\end{tabular}

in innate immunity of bivalves (Bulgakov et al., 2004). However, the Rhamnose-binding lectin and the Immune lectin receptor 2, two lectin-like immune molecules whose expression profiles differed distinctively between $12 \mathrm{~h}$ and $24 \mathrm{~h}$ infection time, seem to suggest that infections carried out with Vibrio are yet to induce Rhamnose-binding lectin transcript levels above seawater-incubation experiments (Fig. 1a and b), whereas this transcript was markedly higher for both $12 \mathrm{~h}$ and $24 \mathrm{~h}$ Flavobacterium incubations. In contrast, $12 \mathrm{~h}$ and $24 \mathrm{~h}$ infections with Flavobacterium induced higher levels of immune lectin receptor 2 transcripts, above the control seawater-incubation expression experiments.

In a recent transcriptome profiling study, using the Pacific Crassostrea gigas as a model to address immune responses to the virulent Vibrio splendidus and Vibrio aestuarianus bacteria, several immune genes were characterised in relation to the oyster capability to survive pathogenic Vibrio infections, including the Rhamnose-binding lectin, C-type lectin 2 and
Metallothionein IV whose expression were up-regulated in surviving oysters (De Lorgeril et al., 2011). Xue et al. (2010) also evidenced the involvement of a new lysozyme in the oyster Crassostrea virginica which also agrees with the finding that $B$. azoricus lysozyme is up-regulated in Flavobacterium infections. Zhao et al. (2010) demonstrated that the lysozyme mRNA transcript from Venerupis philippinarum clam is most abundantly expressed in gills tissues and hemocytes. This lysozyme is similar to molluscan lysozymes. qPCR analyses using clams infected with $V$. anguillarum, showed that the lysozyme mRNA levels in hemocyte were down-regulated abruptly from $6 \mathrm{~h}$ to $12 \mathrm{~h}$ post-infection and increased to a peak value at $72 \mathrm{~h}$. The qPCR results using gills from mussel infected with V. alginolyticus, V. anguillarum, pool of Vibrios and Flavobacterium revealed a decrease of lysozyme expression levels from $12 \mathrm{~h}$ to $24 \mathrm{~h}$ (Fig. $1 \mathrm{~g}$ and $\mathrm{h}$ ).

The multivariate statistical analyses also hinted at how signaling pathways may be activated in B. azoricus during 


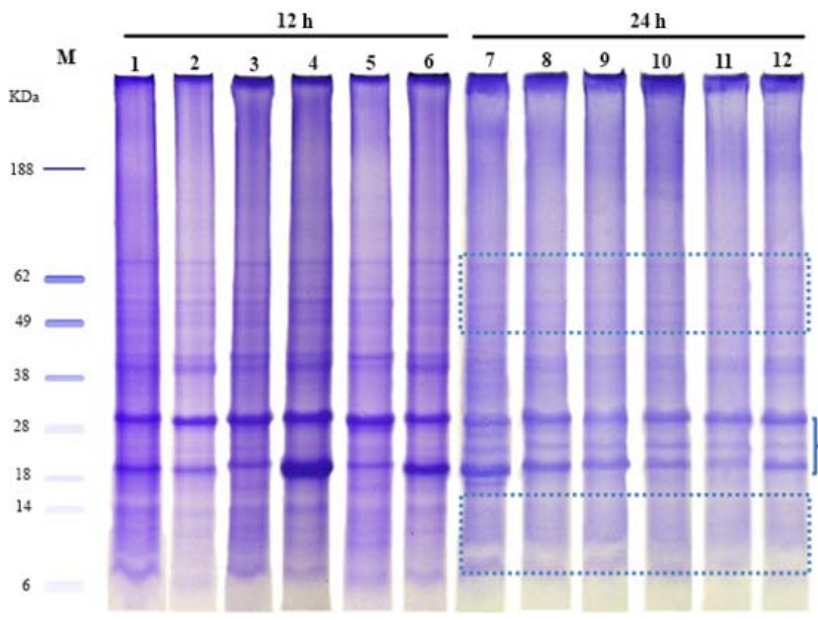

Fig. 9. SDS-PAGE of mix gills protein samples from B. azoricus, incubated in the presence of Seawater, V. splendidus, V. alginolyticus, $V$. anguillarum, pool of Vibrio and Flavobacterium. The lanes $1,2,3,4,5$ and 6 represent samples at $12 \mathrm{~h}$ infection and the lanes 7 , $8,9,10,11$ and 12 correspond to $24 \mathrm{~h}$ infection samples. The rectangles boxes and braces indicate the main differences in protein patterns $(18 \mathrm{kDa})$ between $12 \mathrm{~h}$ and $24 \mathrm{~h}$ of infection. Molecular mass marker $\left(\mathrm{M}\right.$, SeeBlue $\left.{ }^{\circledR}\right)$ is indicated.

immune responses triggered by marine bacteria. The cluster analysis applied to gene expression data was addressed in this study to arrange genes according to similarity in pattern of gene expression. The results were displayed graphically, presenting the clustering and the underlying expression data simultaneously in a form that would help us explore how signaling pathways may be activated in $B$. azoricus during immune responses triggered by marine bacteria. Clustering data using hierarchical clustering R analysis, regarding $12 \mathrm{~h}$ (Fig. 4) and $24 \mathrm{~h}$ post-infection (Fig. 5) gene expression levels, proven to be resourceful in the planning of future experiments involving immune gene expressions that may now be selected on the basis of their relativeness and similarity in pattern of gene expression as evidenced in our analyses by the establishment of distinct cluster groups. The hierarchical clustering approach as dendrograms and/or Heatmaps provided clear examples in our study of such clustering making that included Aggrecan, STAT-SH2 and EGF within the same cluster. Aggrecan is a proteoglycan of the extracellular matrix that can regulate the permeability membrane and is consequently involved in host defense and wound repair (Velleman, 2000; Esko et al., 2009). The STAT gene is involved in mediating functions and is associated with innate immunity (Ihle, 2001), while epidermal growth factor gene (EGF) is associated with proliferation, differentiation of epidermal cells (Tanabe et al., 2008). EGF is activated by signal transducers STAT-SH2, and both were down-regulated in relation to control level expression in the present study. Our results suggested high proximity or relativeness between EGF and STAT-SH2 which are likely linked in cellular processes (Fig. 5).

The genes dendrogram and Heatmap plots support the premise that genes were group according to their function in immune signaling pathways. The gene expression profiles changed according to the bacterial pathogen tested, and the time period of experimental infections. These conditions were statistically confirmed $(p<0.05)$ with Mann-Whitney test and Tukey HSD test. Therefore, it is assumed from this study that B. azoricus mussels were under immune challenging conditions, since comparative results from the control seawater-incubations and Vibrio infections were significantly different.

\section{Conclusions}

This study demonstrates that vent mussels display diverse gene expression profiles that in general decreased from $12 \mathrm{~h}$ to $24 \mathrm{~h}$ time of infections. The immune gene responses were modulated at two levels that are, over the course of time and according to the bacteria tested. Infections carried out with Flavobacterium, induced the highest gene expression ( $56 \%$ of the total genes induced) levels at $12 \mathrm{~h}$ infection time, whereas $V$. splendidus infections revealed greater gene expression levels at $24 \mathrm{~h}$ infection time (50\% of the total genes induced). Also the SDS-PAGE analyses, pointed at differences between $12 \mathrm{~h}$ and $24 \mathrm{~h}$ infection times which could be interpreted as a result of an elevated transcriptional status in animals exposed to Vibrio for $24 \mathrm{~h}$ that in turn ensued in the synthesis of more proteins. Most of the immune genes used in this experimental study seemed to be generally downregulated upon Vibrio and Flavobacterium infection, a phenomenon that we relate to specific dynamics, between microorganisms from the extracellular milieu and B. azoricus gill epithelial cells that comprise specific immune responses and the recruitment of distinct signaling pathways as well as the presence of endosymbiont bacteria.

Taken together, we analysed the effect of bacterial infections in our mussel species while focusing our experiments on infections conducted at atmospheric pressure and not simulating "natural environment" found at hydrothermal vents. In this way, our deep-sea vent mussel became a "shallowwater" animal model while keeping its deep-sea vent genomic "make-up" and transcriptional capabilities (responsiveness), in our land-based aquarium system, without the characteristic hydrostatic pressure levels found at the deepsea vent environments. Our results concur with other's published work, in the field of innate immunity, combining highthroughput and transcriptome sequencing analyses with experimental data obtained by means of quantitative PCR and pointing at the up-regulation of canonical genes involved in innate immunity. 


\begin{abstract}
Appendix A
B. azoricus Protein Sequence

1 MCDEDVAALV VDNGSGMCKA GFAGDDAPRA VFPSIVGRPR HQGVMVGMGQ

51 KDSYVGDEAQ SKRGILTLKY PIEHGIVTNW DDMEKIWHHT FYNELRVAPE

101 EHPVLLTEAP LNPKANREKM TQIMFETFNS PAMYVAIQAV LSLYASGRTT

151 GIVLDSGDGV SHTVPIYEGY ALPHAIIRLD LAGRDLTDYQ MKILTERGYS

201 FTTTAEREIV RDIKEKLCYV ALDFEQEMQT AASSSSLEKS YELPDGQVIT

251 IGNERFRAPE ALFQPSFLGM ESAGVHETTF NSIGKCDIDI RKDLYANTVL

301 SGGTTMFPGI ADRMQKEISA LAPPTMKIKI IAPPERKYSV WIGGSILASL

351 STFQQMWISK QEYDESGPSI VHRKCF
\end{abstract}

Acknowledgements. We are grateful to the Portuguese Foundation for Science and Technology (FCT) for the doctoral grant to E. Martins (SFRH/BD/68951/2010) and to B. Allam (Stony Brook University, NY, USA), A. Figueras, (CSIC, IIM, Vigo, Spain) who kindly provided the Vibrio strains used in this study and to S. Stefanni for helpful comments. We acknowledge the EU FP7 project HERMIONE (grant agreement no. 226354). IMAR-DOP/UAz (R\&D centre \#531) and LARSyS Associated Laboratory are supported by FCT-IP, under the strategic projects (Pest/OE/EEI/LA0009/2011-12 \& 2013-2014) and by DRCT Regional Government of the Azores through a Pluriannual Funding scheme. This work was also supported by the FCT research project IMUNOVENT PTDC/MAR/65991/2006, granted to R. Bettencourt.

The service charges for this open access publication have been covered by IMAR and LARSyS-Associated Laboratory through the funding of FCT/MCE project Pest/OE/EEI/LA0009/2013-14.

Edited by: R. Danovaro

\section{References}

Akira, S. and Hemmi, H.: Recognition of pathogen-associated molecular patterns by TLR family, Immunol. Lett., 85, 85-95, 2003.

Alain, K., Zhinden, M., Le Bris, N., Lesongeur, F., Quérellou, J., Gaill, F., and Cambon-Bonavita, M.-A.: Early steps in microbial colonization processes at deep-sea hydrothermal vents, Environ. Microbiol., 6, 227-241, 2004.

Beaz-Hidalgo, R., Balboa, S., Romalde, J. L., and Figueras, M. J.: Diversity and pathogenicity of Vibrio species in cultured bivalve molluscs, Environ. Microbiol. Report, 2, 34-43, 2010.

Bernardet, J. F., Segers, P., Vancanneyt, M., Berthe, F., Kersters, K., and Vandamme, P.: Cutting a Gordian Knot: Emended Classification and Description of the Genus Flavobacterium, Emended Description of the Family Flavobacteriaceae, and Proposal of Flavobacterium hydatis nom. nov. (Basonym, Сytophaga aquatilis Strohl and Tait1978), Int. J. Syst. Bacteriol., 46, 128-148, 1996.

Bettencourt, R., Roch, P., Stefanni, S., Rosa, D., Colaço, A., and Santos, R. S.: Deep sea immunity: unveiling immune constituents from the hydrothermal vent mussel Bathymodiolus azoricus, Mar. Environ. Res., 64, 108-127, 2007.
Bettencourt, R., Dando, P., Collins, P., Costa, V., Allam, B., and Serrão Santos, R.: Innate immunity in the deep sea hydrothermal vent mussel Bathymodiolus azoricus, Comp. Biochem. Physiol., 152, 278-289, 2008.

Bettencourt, R., Pinheiro, M., Egas, C., Gomes, P., Afonso, M., Shank, T., and Santos, R.: High-Throughput sequencing and analysis of the gill tissue transcriptome from the deep-sea hydrothermal vent mussel Bathymodiolus azoricus, BMC Genomics, 11, 559-576, 2010.

Blasius, A. L. and Beutler, B.: Intracellular Toll-like Receptors Rev., Immunity Cell Press, 32, 305-315, 2010.

Boudsocq, M., Willmann, M. R., McCormack, M., Lee, H., Shan, L., He, P., Bush, J., Cheng, S., and Sheen, J.: Differential innate immune signalling via $\mathrm{Ca} 2+$ sensor protein kinases, Nature, 464, 418-422, 2010.

Bulgakov, A. A., Park, K. I., Choi, K. S., Lim, H. K., and Cho, M.: Purification and characterisation of a lectin isolated from the Manila clam Ruditapes philippinarum in Korea Fish Shell, Immunol., 16, 487-499, 2004.

Bustin, S. A., Benes, V., Garson J. A., Hellemans, J., Huggett, J., Kubista, M., Mueller, R., Nolan, T., Pfaffl, M. W., Shipley, G. L., Vandesompele, J., and Wittwer, C. T.: The MIQE Guidelines: Minimum Information for Publication of Quantitative Real-time Experiments Rev., Clin. Chem., 55, 554-611, 2009.

Cheng, T. C.: Bivalves in invertebrate blood cells, London Academic Press, edited by: Ratcliffe, N. A. and Rowley, A. F., 233299, 1981.

Childress, J. J. and Fisher, C. R.: The biology of hydrothermal vent animals: physiology, biochemistry, and autotrophic symbioses, Oceanogr. Mar. Biol., 30, 337-441, 1992.

Colaço, A., Bettencourt, R., Costa, V., Lino, S., Lopes, H., Martins, I., Pires, L., Prieto, C., and Serrão Santos, R.: LabHorta: a controlled aquarium system for monitoring physiological characteristics of the hydrothermal vent mussel Bathymodiolus azoricus, Ices J. Mar. Sci., 68, 349-356, 2010.

De Chaine, E. G., Bates, A. E., Shank, T. M., and Cavanaugh, C. M.: Off-axis symbiosis found: Characterisation and biogeography of bacterial symbionts of Bathymodiolus mussels from Lost City hydrothermal vents, Environ. Microbiol., 8, 1902-1912, 2006.

De Lorgeril, J., Zenagui, R., Rosa, R. D., Piquemal, D., and Bachére, E.: Whole Transcriptome Profiling of Successful Immune Response to Vibrio Infections in the Oyster Crassostrea gigas by Digital Gene Expression Analysis, PLoS ONE, 6, e23142, doi:10.1371/journal.pone.0023142, 2011.

Demírcan, D. and Candan, A.: Identification of Vibrio anguillarum by PCR (rpoN Gene) Associated with Vibriosis in Marine Fish in Turkey, Turk. J. Vet. Anim. Sci., 30, 305-310, 2006.

Duperron, S., Lorion, J., Samadi, S., Gros, O., and Gaill, F.: Symbioses between deep-sea mussels (Mytilidae: Batymodiolinae) and chemosynthetic bacteria: diversity, function and evolution, C. R. Biol., 332, 299-310, 2009.

Endo, Y., Nakazawa, N., Iwaki, D., Takahashi, M., Matsushita, M., and Fujita, T.: Interactions of Ficolin and MannoseBindingLectin with Fibrinogen/Fibrin Augment the Lectin Complement Pathway, J. Innate Immun., 2, 33-42, 2010.

Esko, J. D., Kimata, K., and Lindahl, U.: Proteoglycans and Sulfated Glycosaminoglycans Chap.16 Essentials of Glycobiology, 2nd ed., edited by: Varki, A., Cummings, R. D., Esko, J. D., Freeze, H. H., Stanley, P., Bertozzi, C. R., Hard, G. W., and Et- 
zler, M. E., Cold Spring Harbor (NY): Cold Spring Harbor Laboratory Press, 2009.

Feng, S. Y.: Cellular defense mechanisms of oysters and mussels, Am. Fish. S. S., Special Publication, 18, 153-168, 1988.

Galloway, T. and Depledge, M.: Immunotoxicity in invertebrates: measurement and ecotoxicological relevance, Ecotoxicology, 10, 5-23, 2001.

Gómez-León, J., Villamil, M. L., Novoa, B., and Figueras, A.: Isolation of Vibrio alginolyticus and Vibrio splendidus from Aquacultured Carpet Shell Clam (Ruditapes decussatus), Larvae Associated with Mass Mortalities, Appl. Environ. Microb., 71, 98-104, 2005.

Grum, M. and Atieno, F.: Statistical analysis for plant genetic resources: clustering and indices in R made simple, Handbooks for Genebanks, No. 9, Bioversity International, Rome, Italy, 2007.

Hasan, N. A., Grim, C. J., Lipp, E., Rivera, I., N. G., Chun, J., Haley, B., Taviani, E., Hoq, M., Munk, C., Brettin, T. S., Bruce, D. C., Challacombe, J., Detter, C., Han, C. S., Eisen, J., Huq, A., and Colwell, R. R.: Deep Sea Bacteria Related to Human Pathogenic Vibrio Species, Vibrios in the environment conference, 2010.

Ihle, J. N.: The Stat family in cytokine signaling, Curr. Opin. Cell Biol., 13, 211-217, 2001.

Janeway, J. and Medzhitov, R.: Innate immune recognition, Annu. Rev. Immunol., 20, 197-216, 2002.

Kilpatrick, D. C.: Animal lectins: a historical introduction and overview, Biochim. Biophys. Acta, 1572, 187-197, 2002.

Kumar, H., Kawai, T., and Akira, S.: Pathogen recognition in the innate immune response, Biochem J. Rev. Art., 420, 1-16, 2009.

Labreuche, Y., Lambert, C., Soudant, P., Boulo, V., Huvet, A., and Nicolasa, J.-L.: Cellular and molecular hemocyte responses of the Pacific oyster, Crassostrea gigas, following bacterial infection with Vibrio aestuarianus strain 01/32, Microb. Infect., 8, 2715-2724, 2006.

Livak, K. and Schmittgen, T. D.: Analysis of relative gene expression data using real-time quantitative PCR and the 2(-Delta Delta C(T)) method, Methods, 25, 402-408, 2001.

May, R. C. and Machesky, L. M.: Phagocytosis and the actin cytoskeleton, J. Cell Sci., 114, 1061-1077, 2001.

Medzhitov, R.: Toll-like receptors and Innate immunity, Nat. Rev. Immunol., 1, 134-145, 2001.

Medzhitov, R.: Recognition of microorganisms and activation of the immune response, Insight Rev. Nature, 449, 819-826, 2007.

Paillard, C., Le Roux, F., and Borrego, J.: Bacterial disease in marine bivalves, a review of recent studies: Trends and evolution, Aquat. Living Resour., 17, 477-498, 2004.
Raguénès, G., Christen, R., Guezennec, J., Pignet, P., and Barbier, G.: Vibrio diabolicus sp. nov., a New Polysaccharide-Secreting Organism Isolated from a Deep-sea Hydrothermal Vent Polychaete Annelid, Alvinella pompejana, Int. J. Syst. Bacteriol., 47, 989-995, 1997.

Salerno, J., Macko, S. A., Hallam, S. J., Bright, M., Won, Y., Mckiness, and van Dover, C.: Characterisation of Symbiont Populations in Life-History Stages of Mussels from Chemosynthetic Environments, Bull. Marine Biol. Lab., 208, 145-155, 2005.

Sancho, D. and Sousa, C. R.: Signaling by Myeloid C-Type Lectin Receptors in Immunity and Homeostasis, Annu. Rev. Immunol., 30, 491-529, 2012.

Tanabe, K. K., Pharm, A. L., Finkelstein, D. M., Kawasaki, H., Fujii, T., Chung, R. T., Lauwers, G. Y., Kulu, Y., Muzikansky, A., Kuruppu, D., Lanuti, M., Goodwin, J. M., Azoulay, D., and Fuchs, B. C.: Epidermal Growth Factor Gene Functional Polymorphism and the Risk of Hepatocellular Carcinoma in Patients With Cirrhosis, JAMA-J. Am. Med. Assoc., 299, 53-60, 2008.

Teske, A.: Deep-Sea Hydrothermal vents, The Desk Encyclopedia of Microbiology 2nd Edition by Moselio Schaechter, Academia press, 346-356, 2009.

Teske, A., Brinkhoff, T., Muyzer, G., Moser, D. P., Rethmeier, J., and Jannaschi, H. W.: Diversity of Thiosulfate-Oxidizing Bacteria from Marine Sediments and Hydrothermal Vents, Appl. Environ. Microb., 66, 3125-3133, 2000.

Toranzo, A. E. and Barja, J. L.: A review of the taxonomy and seroepizootiology of Vibrio anguillarum, with special reference to aquaculture in the northwest of Spain, Diseas. Aquat. Org., 9, 73-82, 1990.

Velleman, S. G.: The Role of the Extracellular Matrix in Skeletal Development, Poultry Sci., 79, 985-989, 2000.

Xue, Q. G., Hellberg, M. E., Shecy, K. L., Itoh, N., Eytan, R. I., Cooper, R. K., and La Peyre, J. F.: A new Lysozyme from the eastern oyster, Crassostrea virginica, and a possible evolutionary pathway for i-type lysozymes in bivalves from host defense to digestion, BMC Evol. Biol., 10, 1-17, 2010.

Zhao, J., Qiu, L., Ning, Z., Chen, A., Wu, H., and Li, C.: Cloning and characterisation of an invertebrate type lysozyme from Venerupis philippinarum. Comp. Biochem. Physiol., B. Biochem. Mol. Biol., 156, 56-60, 2010. 